\title{
SUCCESSFUL AREA-WIDE PROGRAMME THAT ERADICATED OUTBREAKS OF THE INVASIVE CACTUS MOTH IN MEXICO
}

\author{
A. BELLO-RIVERA ${ }^{1}$, R. PEREIRA ${ }^{2}$, W. ENKERLIN ${ }^{2}$, S. BLOEM ${ }^{3}$, \\ K. BLOEM ${ }^{4}$, S. D. HIGHT ${ }^{5}$, J. E. CARPENTER ${ }^{6}$, \\ H. G. ZIMMERMANN ${ }^{7}$, H. M. SANCHEZ-ANGUIANO ${ }^{8}$, \\ R. ZETINA-RODRIGUEZ ${ }^{9}$ AND F. J. TRUJILLO-ARRIAGA ${ }^{1}$
}

${ }^{1}$ Dirección General de Sanidad Vegetal, SENASICA-SAGARPA, Ciudad de México,
C.P. 04530, México; arturo.bello@senasica.gob.mx
${ }^{2}$ Insect Pest Control Section, Joint FAO/IAEA Division of Nuclear Techniques in
Food and Agriculture, Vienna, Austria
${ }^{3}$ NAPPO, 1730 Varsity Drive Suite 145, Raleigh, NC 27606, USA
${ }^{4}$ USDA-APHIS-PPQ, 1730 Varsity Drive Suite 400, Raleigh, NC 27606, USA
${ }^{5}$ USDA-ARS-CMAVE, Centre for Biological Control, FAMU, Tallahassee, FL
32308, USA
${ }^{6}$ Retired, Tifton, Georgia, USA (former USDA-ARS)
${ }^{7}$ Retired, Pretoria, South Africa (former ARC-LNR)
${ }^{8}$ OIRSA, Ciudad de México, C. P. 11590, México
${ }_{9}^{9}$ Representación Regional 6 SENASICA, San Francisco de Campeche, Campeche

\section{SUMMARY}

The spectacular success of the cactus moth, Cactoblastis cactorum (Berg), in controlling invasive Opuntia species has been cited often in biological control literature. This insect is highly damaging to plants of the Cactaceae family and has been regarded as one of the most successful classical weed biological control agents. In Australia, the cactus moth effectively controlled approximately 25 million hectares of non-native Opuntia species that had invaded cattle grazing lands. In Mexico, however, the Cactaceae are native, where they have their greatest diversity, and have major ecological and socio-economic importance. In the 1950s,

J. Hendrichs, R. Pereira and M. J. B. Vreysen (eds.), Area-Wide Integrated Pest Management: Development and Field Application, pp. 561-580. CRC Press, Boca Raton, Florida, USA. (C) 2021 IAEA 
the cactus moth was introduced into several Caribbean islands for management of Opuntia spp. on grazing lands. The moth arrived accidentally in Florida by 1989, and concerns were raised that this highly mobile moth could spread into the south-western USA and reach Mexico. Therefore, a cactus moth surveillance programme was established in Mexico in 2002 to detect and prevent the introduction and establishment of this invasive pest. Through this detection trapping network, two localized but large outbreaks of $C$. cactorum were detected off the coast of the Peninsula of Yucatán, Mexico; on Isla Mujeres, 10 August 2006, and Isla Contoy, 4 May 2007, both in the municipality of Isla Mujeres in the state of Quintana Roo. An eradication programme was immediately implemented by the National Service for Health, Safety and Food Quality (SENASICA) of the Ministry of Agriculture, Livestock, Rural Development, Fisheries and Food (SAGARPA) of Mexico, in close collaboration with other national and international organizations. An area-wide integrated pest management (AW-IPM) approach was implemented that included regulatory actions, outreach activities, surveillance, intensive sanitation and the release of sterile moths. Eradication was achieved in 2008 and officially declared in 2009. A surveillance network is currently maintained for detecting early pest incursions, allowing for a rapid response to any future incursion of the pest. This successful programme has resulted in the protection of the high value commercial Opuntia cacti industry in Mexico, as well as native Opuntia species in natural arid and semi-arid ecosystems where they are an essential element in maintaining biodiversity and soil conservation.

Key Words: Opuntia, prickly pear cactus, Cactoblastis cactorum, Sterile Insect Technique, sterile moths, biological control, AW-IPM, Yucatán, Quintana Roo

\section{INTRODUCTION}

In general, biological control is the use of one organism to reduce the population density of another organism. Biological control has been used by humans for about two millennia and has become widely used in pest management programmes since the end of the nineteenth century (DeBach 1964; van Lenteren and Godfray 2005). Classical biological control involves the introduction of a host-specific, non-native natural enemy adapted to a non-native organism that became a pest in its new homeland. Classical weed biological control implies the importation of natural enemies to control a non-native weed species.

The South American cactus moth, Cactoblastis cactorum (Berg) (Lepidoptera: Pyralidae), is a well-known example demonstrating the great success that can be achieved using plant-feeding insects as classical biological control agents of invasive plants (Dodd 1940; Pettey 1948, Zimmermann et al. 2004). The removal of highly invasive species of prickly pear cacti (Opuntia spp.) from millions of hectares (ha) of Australian farmland, rangeland, and natural habitat was a great early success in biological control of weeds. The dramatic "before and after" pictures of devastated dense cactus vegetation after releasing C. cactorum (Dodd 1940) are familiar examples of the stunning impact of successful classical biological weed control (DeBach et al. 1976).

Several programmes resulted in successes similar to the programme in Australia, including South Africa and Hawaii (Zimmermann et al. 2000, 2004). However, in 1956 the decision was made to release C. cactorum on the Caribbean island of Nevis, part of the Leeward Islands group of the West Indies, where Opuntia species occurred 
that were native. Control of Opuntia on Nevis Island was deemed important to help manage a complex of native prickly pears dominated by Opuntia triacantha (Willdenow) and introduced species that were considered a serious weed pest in overgrazed rangeland where they outcompeted grasses and caused injury to livestock and animal handlers (Simmonds and Bennett 1966). Three species of natural enemies, including C. cactorum, were shipped from South Africa and released on Nevis Island in early 1957. C. cactorum was apparently the only natural enemy that became established, spreading rapidly and causing the collapse of prickly pear populations on the island. This biological control programme was considered "outstandingly successful" (Simmonds and Bennett 1966).

Based upon these successes, C. cactorum was introduced on the islands of Montserrat and Antigua in 1960, where it also became established and caused substantial reduction of native prickly pear populations (Simmonds and Bennett 1966). Thereafter, C. cactorum continued spreading, either naturally or with intentional or unintentional human involvement, through many regions of the Caribbean, including Puerto Rico, the U.S. Virgin Islands, the Dominican Republic, the Bahamas, and Cuba, where it attacked native Opuntia spp. (Zimmermann et al. 2000).

In 1989, C. cactorum was discovered on native Opuntia spp. in southern Florida, USA (Habeck and Bennett 1990; Dickel 1991) and received considerable attention in view of its potential negative ecological and economic impact in the southern and western USA (Simberloff et al. 1996). How the moth arrived in Florida is unclear. The moth may have arrived through natural dispersal by flight, possibly storm-aided, since the moth was established in Cuba, only $128 \mathrm{~km}$ from the Florida Keys (Zimmermann et al. 2000). Perhaps the most compelling explanation for the expansion of C. cactorum was proposed by Pemberton (1995), who suggested that the moth may have been unintentionally introduced through commerce of ornamental cactus. During the 1980s, 300,000 Opuntia plants destined for nursery sales were shipped from the Dominican Republic to Miami every year. From 1981-1986, C. cactorum was intercepted 13 times at Miami ports, including larvae found in stems of Opuntia plants from the Dominican Republic (Pemberton 1995).

Molecular genetic analysis of C. cactorum specimens from Florida also supports the hypothesis that multiple introductions into Florida occurred from a location outside the insects' native range in South America (Simonsen et al. 2008; Marsico et al. 2011).

Thus $C$. cactorum had become an invasive species with a high biotic potential. Although the moth is not a typical long-distance flyer, with a maximum recorded dispersal distance of $24 \mathrm{~km}$ (S. D. Hight unpublished data), it has a high reproductive capacity with egg sticks usually consisting of 70-90 eggs, sometimes up to 120 eggs, and a female that produces three or four egg sticks during her lifetime (Zimmermann et al. 2004). "A worm that turned" is the title of a popular article that describes the threat of the same "miracle" insect when its host plants were no longer considered weeds, but native cacti of great economic, ecological and aesthetic value (Stiling 2000). 
Over a period of 20 years, this invasive moth has been spreading from southern Florida as far north as central coastal South Carolina and as far west as coastal Louisiana (Hight et al. 2002; Hight and Carpenter 2009). In 2017, the moth was found in southern North Carolina, approximately $160 \mathrm{~km}$ from the last known location of $C$. cactorum in South Carolina (Jarred Driscoll, North Carolina Department of Agriculture, personal communication).

In view of this threat, already in 2002, Mexico initiated a surveillance campaign for $C$. cactorum under the National Preventive Campaign against Cactus Moth, with the purpose of early detection of any incursion. This surveillance network detected two outbreaks of C. cactorum in the state of Quintana Roo, Yucatán Peninsula, i.e. on 10 August 2006 on Isla Mujeres and on 4 May 2007 on Isla Contoy, both within the municipality of Isla Mujeres (Hight and Carpenter 2009) (Fig. 1).

Also because of concerns of the growing threat to native and cultivated Opuntia species with the continued spread of the cactus moth, the USA and Mexico developed a Bi-National Cactus Moth Programme in 2006 that was implemented with funding from both countries. Operations supported by the Bi-National Cactus Moth Programme were initially directed at suppressing populations and containing the leading edge of the infestation in the USA along the Gulf Coast of Florida, Alabama, and Mississippi (Bloem et al. 2007; Carpenter et al. 2008). When the two outbreaks occurred in Quintana Roo in 2006, the Bi-National Programme also supported eradication efforts in Mexico.

In this paper we describe the development of a surveillance and eradication programme that was implemented by the Government of Mexico in close collaboration with the USA and with other national and international organizations.

\section{THE IMPORTANCE OF OPUNTIA CACTI IN MEXICO}

The genus Opuntia is one of the most widely used plants in Mexico and Central America. Due to the high protein and fibre content in the stems, or pads, and the amount of water in their tissue (88-91\%, Pimienta-Barrios 1990). Opuntia cacti have an extremely wide range of uses, from human and animal food to cosmetics and adhesives (Barbera 1995). In Mexico, traditional uses of Opuntia vary widely although there are two main products that account for the economic importance of Opuntia products: food and fodder (Pimienta-Barrios 1990; Barbera 1995).

Fodder is mainly for cattle and goats in all parts of Mexico, but its use for forage has been documented in many other parts of the world including the USA, northern and southern Africa, and several South American countries (Felker 1995). In Brazil, for example, close to 300000 ha has been planted with Opuntia cacti to produce fodder for livestock (Barbera 1995). Opuntia spp. have been cultivated worldwide because of the value of the plants as ornamental and agricultural commodities, and their ability to adapt to various climatic conditions, particularly to semi-arid and arid areas (Hanselka and Paschal 1989). 
Opuntia spp., which have been important cultural and agricultural plants in Mesoamerica since the pre-Hispanic era (Zimmermann and Pérez-Sandi-Cuen 2006), annually generate over 300000 tons of fruit and vegetables in Mexico, and are cultivated on more than 70000 ha (Pimienta-Barrios 1990; Flores-Valdez et al. 1995; Soberón et al. 2001). As food, Opuntia can be consumed as a vegetable (by dicing young pads - "nopalitos") or as a fruit (tuna or cactus pear). The fruits are produced in 15 out of 32 Mexican states employing close to 20000 people, whereas vegetables are produced in 14 states and employ close to 8000 people. In addition, most rural people consume prickly pear from local wild Opuntia populations and family-owned plantations maintained at various sizes. The average income generated by Opuntia products over the period 1990-1998 is approximately 50 million USD per year, with vegetable usage constituting more than half of the value (USD 27 million), followed by cactus pears (USD 20 million), and finally fodder (USD 1 million). In addition, the export market of Opuntia products is valued at USD 50 million per year. Exports are mainly to the U.S., Canada, Europe, and Japan (Soberón et al. 2001). If C. cactorum were to establish in Mexico, ca. 30000 producers of cactus fruit and vegetable would be affected, as well as the nopal processing industries.

Mexico is recognized as the origin of the genus Opuntia (Esparza et al. 2004) and has the highest number of cultivated species and varieties of prickly pear in the world (19 cultivated types in total) (Flores-Valdez and Gallegos 1993). Mexico also has one of the highest diversity of species of the genus Opuntia (in addition to Cactaceae biodiversity of ca. 560 species) that cover an area of close to 3000000 ha $(1.5 \%$ of Mexican territory). The actual number of Opuntia species varies in the literature, partially because of frequent hybridization between species and the lack of a standardized taxonomic classification. Bravo-Hollis (1978) recognized 104 species of Opuntia in Mexico, 56 of which are in the subgenus Platyopuntia (prickly pears), 38 of which are endemic. From an ecological point of view, loss of acreage covered by Opuntia species would accelerate soil loss in arid and semi-arid areas, and the loss of ecological niches to a variety of organisms (Ojeda 2004).

\section{FIRST DETECTION IN MEXICO}

The two C. cactorum outbreak sites (Isla Mujeres and Isla Contoy) were located in the state of Quintana Roo, one of the 32 states of Mexico. This state is part of the Yucatán Peninsula in the south-eastern part of the country, bordering to the north with the state of Yucatán and the Gulf of Mexico, to the east with the Caribbean Sea, to the south with Belize, and to the west with the state of Campeche. Its capital is Chetumal and its most populous city is Cancún.

First outbreak site: Isla Mujeres is a small island located in the Caribbean Sea, 13 $\mathrm{km}$ off the coast of the Yucatán Peninsula (Fig. 1). The island is $7 \mathrm{~km}$ long and on average $1 \mathrm{~km}$ wide (for a total of $455 \mathrm{ha}$ ), and it is part of one of the eleven municipalities in the state of Quintana Roo. The municipality of Isla Mujeres, which 
includes a part of continental territory, is located $13 \mathrm{~km}$ from the city of Cancún, the main tourist attraction in the region. Isla Mujeres has a permanent settlement of approximately 16000 inhabitants whose primary livelihood is to support the tourist industry. The island is accessed from Cancún by vehicle and passenger ferryboats. Delimiting trapping revealed that the size of the outbreak area was 45 ha infested with moth populations following the spatial distribution of its Opuntia hosts scattered over much of the island but concentrated on the southern end.

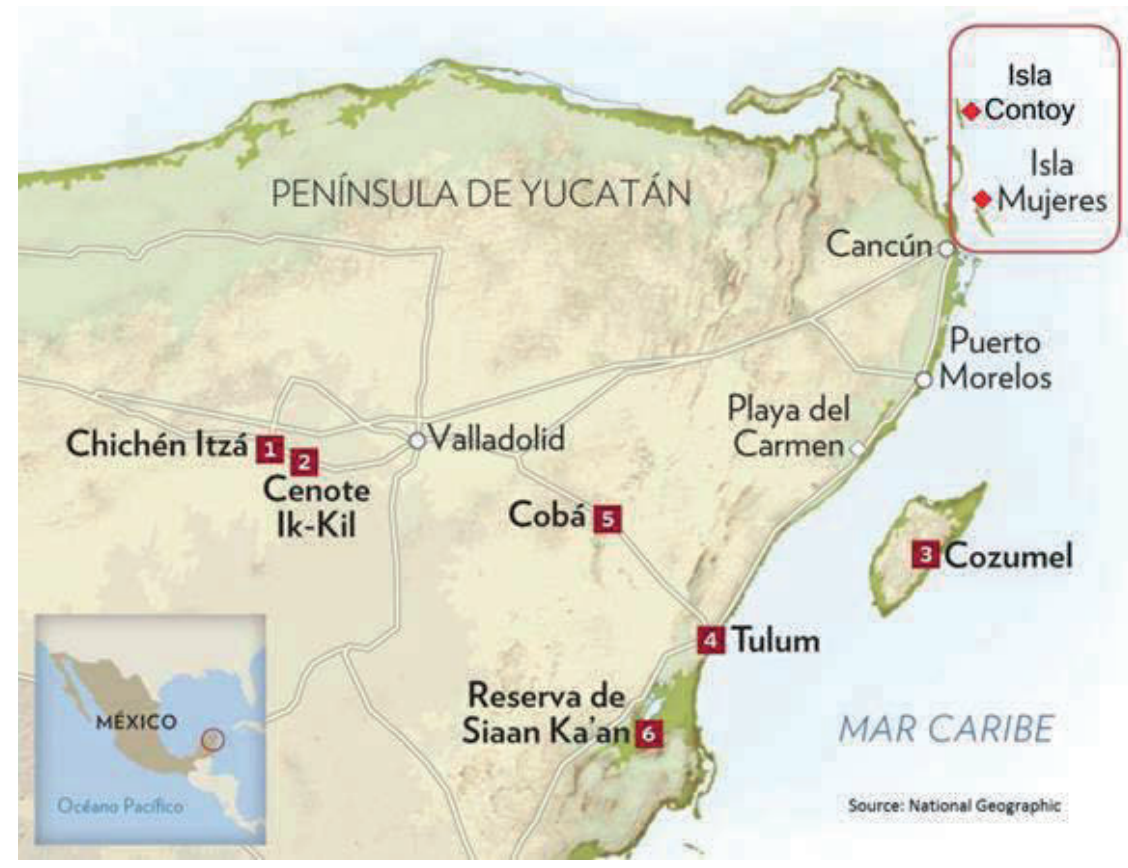

Figure 1. Location of Isla Mujeres and Isla Contoy near Cancun, Quintana Roo, in the Caribbean Sea, where populations of Cactoblastis cactorum were detected, but were later eradicated.

Second outbreak site: Isla Contoy (Fig. 1) is an even smaller island, also belonging to the municipality of Isla Mujeres and located $30 \mathrm{~km}$ north of Isla Mujeres. The island is $8.75 \mathrm{~km}$ long, and on average $0.5 \mathrm{~km}$ wide, and has a surface area of $317 \mathrm{ha}$. In 1961, the Mexican government declared the island a protected area and a bird sanctuary, and in 1998, it was declared a national park. The island is known as "The Island of the Birds" due to the large numbers of frigate birds and other oceanic avian species that use Isla Contoy as a nesting location. 
To the south of the island is the Ixlaché reef that is part of the second largest barrier reef in the world. The National Park Service maintains a small visitor's centre and housing for visiting researchers on the island. Access by tourists to the island is controlled and monitored by the National Park Service. Delimiting trapping revealed that the size of the outbreak area was 3 ha with the moth population somewhat limited to dense stands of Opuntia host plants in the central part of the island.

\section{FORMATION OF OPERATIONAL PROGRAMME}

A number of national and international institutions and organizations joined efforts in the fight against these cactus moth outbreaks. These included: The Food and Agriculture Organization of the United Nations (FAO), the International Atomic Energy Agency (IAEA), the United States Department of Agriculture (USDA), the North American Plant Protection Organization (NAPPO), and the Mexican Government through the Ministry of Agriculture, Livestock, Rural Development, Fisheries and Food (SAGARPA), the National Service for Health, Safety and Food Quality (SENASICA) and the National Forestry Commission (CONAFOR). Technical and economic support was provided to research and development (R\&D) and to the implementation of an area-wide eradication programme.

\section{RESEARCH AND DEVELOPMENT}

The necessary tools for implementation of the eradication programme were developed through effective research and development. These included: determination of the moth's mating behaviours (Hight et al. 2003), design and evaluation of trapping systems (Bloem et al. 2005a), pheromone identification and synthesis (Heath et al. 2006; Cibrián-Tovar 2009; Cibrián-Tovar et al. 2017), population ecology studies including dispersal (Hight et al. 2002; Bloem et al. 2005a; Sarvary et al. 2008), studies on biology of the pest (McLean et al. 2006), implementation of trials to assess susceptibility to insecticides (Bloem et al. 2005b), development of an artificial diet and mass-rearing tools (Marti and Carpenter 2008; Carpenter and Hight 2012), assessment of the feasibility of biological control (Paraiso et al. 2012) and the Sterile Insect Technique (SIT) (Carpenter et al. 2001; Hight et al. 2005), and assessment of the potential economic, social, and environmental impacts of $C$. cactorum both in the USA and in Mexico (Zimmermann et al. 2004; Simonson et al. 2005; Sánchez et al. 2007).

One of the essential tools that was developed and validated was the trapping system based on a standard (unpainted) wing trap (Bloem et al. 2005a), placed at a height of $2.0 \mathrm{~m}$ above ground, and baited with a rubber septum impregnated with a synthetic female sex pheromone (Heath et al. 2006). Support from the Joint FAO/IAEA Division was essential for transferring the tools for implementing an AWIPM approach integrating the SIT (Dyck et al. 2021). 


\section{PROGRAMME OPERATIONS}

The Mexican Government provided the necessary financial resources for programme operations aimed at eradicating the outbreaks on Islas Mujeres and Contoy. The financial resources to support programme implementation are summarized in Table 1. It is important to point out that when the pest was first detected in Mexico, resources were immediately allocated through the declaration of a National Emergency, which is an instrument of Mexican legislation that allows for timely response to this type of phytosanitary emergency.

To raise awareness of the potential impact of the presence of the cactus moth, the following sectors were alerted and informed: Political and administrative government offices and divisions, academic research and technical institutions, industry stakeholders, commercial agricultural enterprises, natural area managers, growers, farmers and ranchers, non-government agencies, amusement parks, hotels in tourist areas, and the public in general. It was also essential to carry out the necessary feasibility assessments and to support the preparation of public outreach materials such as booklets, videos, and calendars.

Table 1. Total financial resources (USD) made available from 2006 through 2010 for the implementation of cactus moth eradication programme activities by the Mexican Government through the National Service for Health, Safety and Food Quality (SENASICA) and the National Forestry Commission (CONAFOR)

\begin{tabular}{|c|c|c|c|}
\hline Year & $\begin{array}{c}\text { Contribution from } \\
\text { SENASICA }\end{array}$ & $\begin{array}{c}\text { Contribution from } \\
\text { CONAFOR }\end{array}$ & Total \\
\hline 2006 & 192926 & 181818 & 374744 \\
\hline 2007 & 1090909 & 0 & 1090909 \\
\hline 2008 & 772727 & 34386 & 807114 \\
\hline 2009 & 318182 & 0 & 318182 \\
\hline 2010 & 240000 & 0 & 240000 \\
\hline Total & 2614744 & 216205 & 2830949 \\
\hline
\end{tabular}

The cactus moth eradication programme in Mexico followed a similar AW-IPM approach and operational tactics as had been used to suppress and contain the pest in the USA along the Gulf of Mexico. These included: regulatory actions, raising public awareness, extensive surveys, sanitation of infested host plants through mechanical removal as well as removal of egg sticks, and finally the release of sterile moths produced at the USDA insectary in Tifton, Georgia and shipped to Mexico (Table 2). These actions eradicated $C$. cactorum populations in Mexico (Bloem et al. 2007; Hernández et al. 2007; Carpenter et al. 2008; NAPPO 2009; Hight and Carpenter 2016). 
Table 2. Actions implemented to eradicate the cactus moth from Isla Mujeres and Isla Contoy

\begin{tabular}{|c|c|c|c|c|c|}
\hline Actions/Activities & Isla Mujeres & Isla Contoy & $\begin{array}{c}\text { Rest of the } \\
\text { Quintana } \\
\text { Roo }\end{array}$ & $\begin{array}{c}\text { Yucatán and } \\
\text { Campeche }\end{array}$ & $\begin{array}{l}\text { Rest of the } \\
\text { Country }\end{array}$ \\
\hline \multicolumn{6}{|l|}{ Surveillance } \\
\hline Trap deployment and weekly trap checks & $X$ & $X$ & $X$ & $x$ & $X$ \\
\hline $\begin{array}{l}\text { Identification of adult captures with differentiation } \\
\text { between wild and sterile adults }\end{array}$ & $X$ & $X$ & $X$ & & \\
\hline $\begin{array}{l}\text { Identification of sentinel sites and weekly checking of } \\
\text { sentinel plants for egg-sticks oviposited by wild females }\end{array}$ & $X$ & $x$ & & & \\
\hline Review of permanent observation points & & & $X$ & $X$ & $X$ \\
\hline $\begin{array}{l}\text { Identification of suspect detections in cultivated and wild } \\
\text { areas }\end{array}$ & $X$ & $X$ & $X$ & $x$ & $x$ \\
\hline \multicolumn{6}{|l|}{ Pest Control } \\
\hline $\begin{array}{l}\text { Host plant removal (Opuntia dillenii Ker Gawl, Nopalea } \\
\text { cochenillifera (L.) Mill.) }\end{array}$ & $X$ & & & & \\
\hline Eggstick removal & $X$ & $X$ & & & \\
\hline Application of insecticides & $x$ & $x$ & & & \\
\hline Application of herbicides & $X$ & & & & \\
\hline Sterile moth releases & $x$ & $X$ & & & \\
\hline Host census & $X$ & $X$ & $X$ & & \\
\hline $\begin{array}{l}\text { Exchange programme with homeowners of ornamental } \\
\text { Opuntia plants or voluntary surrender by the inhabitants }\end{array}$ & $x$ & & & & \\
\hline \multicolumn{6}{|l|}{ Regulation of host mobilization } \\
\hline $\begin{array}{l}\text { Prohibition of the move-ment of Opuntia plants or their } \\
\text { parts off or within the island }\end{array}$ & $x$ & $X$ & & & \\
\hline Review of transport in the sea ports & $X$ & $X$ & & & \\
\hline \multicolumn{6}{|l|}{ Disclosure and training } \\
\hline Training workshops for staff of programme & $x$ & $x$ & $x$ & $X$ & $x$ \\
\hline Development and dispersal of informative material & $X$ & $X$ & $X$ & $X$ & $X$ \\
\hline $\begin{array}{l}\text { Radio and television spots to educate the public of the } \\
\text { programme and dangers of } C \text {. cactorum outbreak }\end{array}$ & $x$ & $X$ & $X$ & $X$ & $X$ \\
\hline $\begin{array}{l}\text { Meetings with municipal presidencies and local } \\
\text { authorities }\end{array}$ & $X$ & $X$ & $x$ & $x$ & \\
\hline $\begin{array}{l}\text { Meetings with schools, hoteliers and managers of natural } \\
\text { parks }\end{array}$ & $X$ & $X$ & $X$ & & \\
\hline \multicolumn{6}{|l|}{$\begin{array}{l}\text { Supervision and evaluation visits with the following } \\
\text { groups: }\end{array}$} \\
\hline SAGARPA State Delegation & $X$ & $X$ & $X$ & $X$ & $X$ \\
\hline Plant Health General Directorate & $x$ & $x$ & $x$ & $x$ & $x$ \\
\hline Experts from FAO/IAEA & $x$ & $X$ & $x$ & $X$ & \\
\hline Experts from USDA & $X$ & $X$ & $X$ & & \\
\hline Technical Group Meetings & $X$ & $X$ & $X$ & $X$ & $X$ \\
\hline \multicolumn{6}{|l|}{ Technical reports } \\
\hline Data collection & $X$ & $X$ & $X$ & $X$ & $X$ \\
\hline Weekly reports to the Plant Health General Directorate & $X$ & $X$ & $X$ & $X$ & $X$ \\
\hline Reports to the local authorities & $X$ & $X$ & $X$ & & \\
\hline
\end{tabular}


The SENASICA-SAGARPA national surveillance system allowed early detection of pest incursions, followed immediately by the implementation of delimitation and eradication actions to eliminate the two outbreaks of this invasive species. This prevented further dispersal and introduction of the pest to other uninfested areas. The actions that were implemented to eradicate the cactus moth from Isla Mujeres and Isla Contoy are summarized in Table 2.

\section{PROGRAMME RESULTS AND ERADICATION}

\subsection{Surveillance and Control on Isla Mujeres}

Initially 66 traps were deployed on Isla Mujeres, primarily in and around the infested $45 \mathrm{ha}$; this was later expanded to a total of 115 traps. Trapping and host plant sampling and removal soon revealed high infestation levels throughout the island with thousands of egg sticks and larvae collected and destroyed and adult males trapped (Fig. 2). The effect of the rapid and aggressive response from SENASICA personnel was visible almost immediately, and the density of the outbreak population of $C$. cactorum was quickly reduced. A total of 4126 egg sticks were collected from plants during the eradication effort and 321 adult males were trapped.

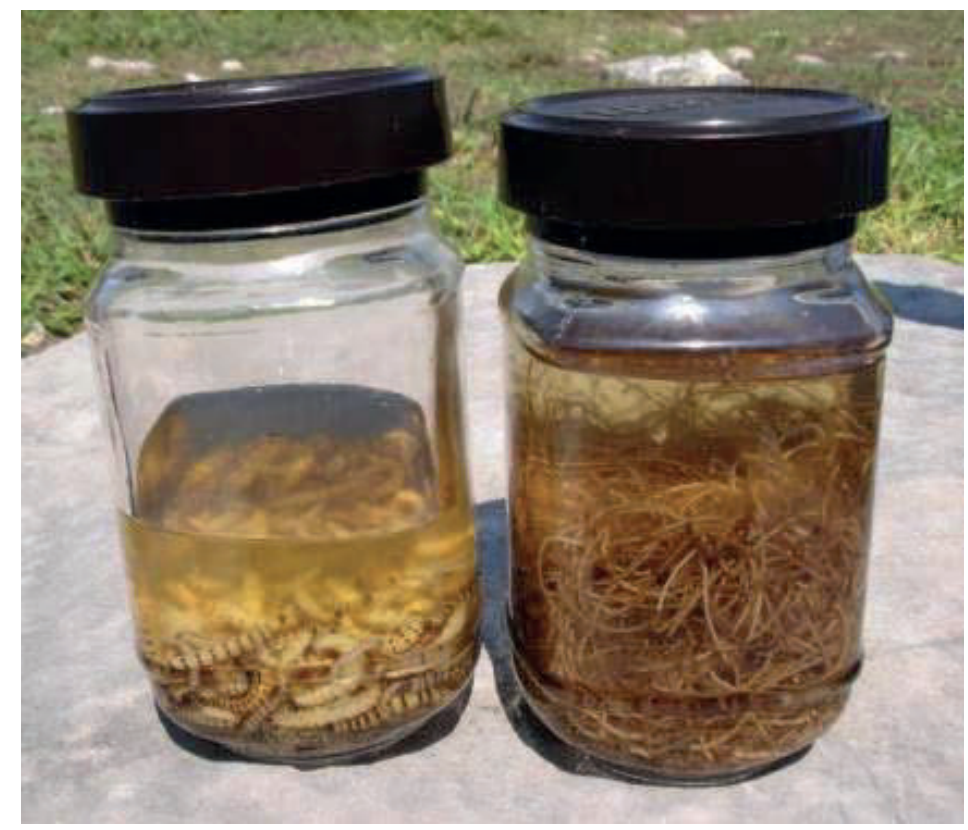

Figure 2. Larvae and egg sticks of Cactoblastis cactorum collected on Isla Mujeres during the initial stages of the eradication programme. 
Once trapping efforts revealed a dispersed infestation over much of the island, removal of above-ground host plant material was conducted to suppress additional $C$. cactorum population increase. As part of the mechanical control, 240 tons of potential and infested host plants were removed throughout the island. Only 27 sentinel host plants remained, which were plants that were easy to access and could be checked daily for the presence of egg sticks or damage caused by the larvae.

Two censuses for Opuntia spp. host plants were carried out in the backyards of homes throughout the island in March and June 2008. A total of 3050 sites with susceptible host plants were identified in private homes, public offices, hotels, and vacant lots. To facilitate the removal of host plants, a protocol was implemented to replace each host plant with a non-host ornamental plant, mainly species of palms (1140 specimens) and magueys (Agave spp.) (74 specimens). CONAFOR kindly provided the replacement plants for this part of the programme.

The population trend of $C$. cactorum on Isla Mujeres is indicated by the weekly total number of egg sticks collected (Fig. 3) and weekly total number of wild males caught (Fig. 4). A drastic reduction in the cactus moth population resulted from the intensive mechanical control and adult mass-trapping. This prepared the ground for the integration of the SIT on an area-wide basis and assured a competitive sterile to wild insect ratio. The targeted initial overflooding ratio was 10 sterile to 1 wild moths as identified in trap captures. In preparation for sterile moth releases, extensive quality control, flight ability, and dispersion tests had been conducted, and shipping techniques evaluated in the USA.

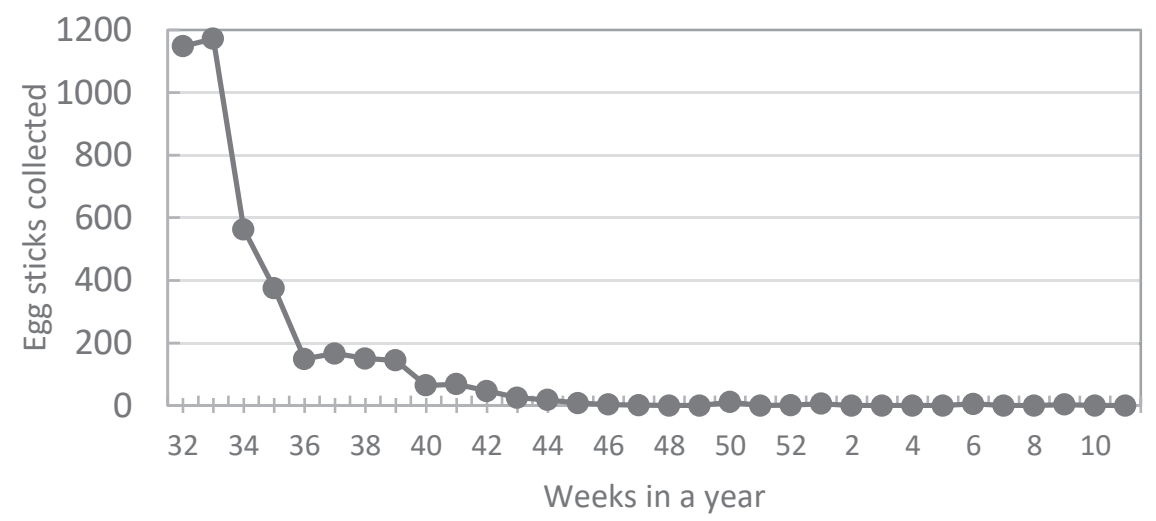

Figure 3. Total C. cactorum egg sticks collected from Opuntia spp. plants each week from August 2006 to March 2007 on Isla Mujeres. Collections were concentrated in an area of 45 ha in the southern end of the island's $455 \mathrm{ha}$. 


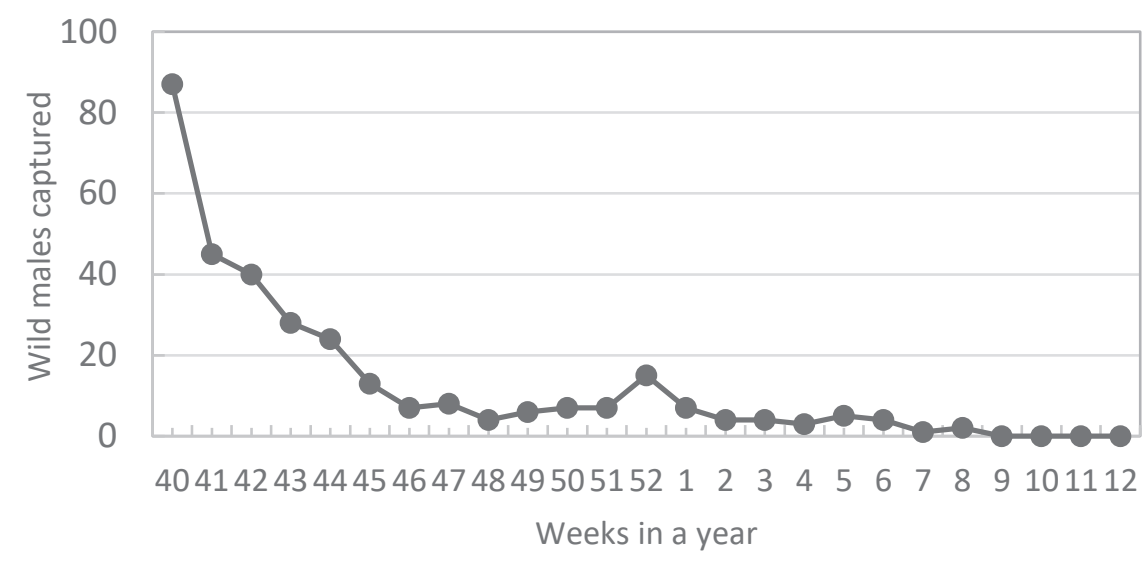

Figure 4. Total wild C. cactorum male moths caught weekly in pheromone-baited traps from October 2006 to March 2007 on Isla Mujeres. Captures were concentrated in an area of 45 ha in the southern end of the island's $455 \mathrm{ha}$.

The first trial of sterile adult moth releases $(n=1398)$ was carried out on Isla Mujeres on 1 November 2007; it primarily targeted to the area where the last egg sticks were collected and the last male $C$. cactorum were captured. Release time frame for packages of shipped sterile moths was within $48 \mathrm{hr}$; from insect packaging, delivery to a USA airport, receipt in Cancún, to release on Isla Contoy.

Given the fact that the last wild individuals were detected during the second week of March 2007 (Fig. 3), it is possible that during the time the sterile moths were released, eradication may have already been achieved. Nevertheless, application of the SIT gave assurance that no remnant of the invasive population of the cactus moth remained.

\subsection{Surveillance and Control on Isla Contoy}

After detection of the cactus moth on 4 May 2007, programme activities were immediately intensified on Isla Contoy. This however, required the processing of access permits, as the island is a protected natural reserve and the cactus vegetation could not be mechanically removed as it was on Isla Mujeres.

A total of 44 traps were deployed and the trap catches indicated that the outbreak was limited to the central part of the island. All larvae found $(n=1028)$ as well as all damaged plant parts $(n=122)$ were removed. Some wild cactus plants exhibited damage caused by another cactophagus moth, presumably of the genus Melitara, which made it difficult to differentiate the damage from that of the cactus moth. 
A total of 46 C. cactorum egg sticks were collected on Isla Contoy (Fig. 5) and a total of 41 wild male adult cactus moths were caught in the traps (Fig. 6).

The first trial release of sterile adult moths $(n=1281)$ was carried out on Isla Contoy on November 7, 2007. After this release, 18 sterile adults were caught in the traps (confirmed in the laboratory), suggesting that the dispersal behaviour and competitiveness of the sterile insects was adequate.

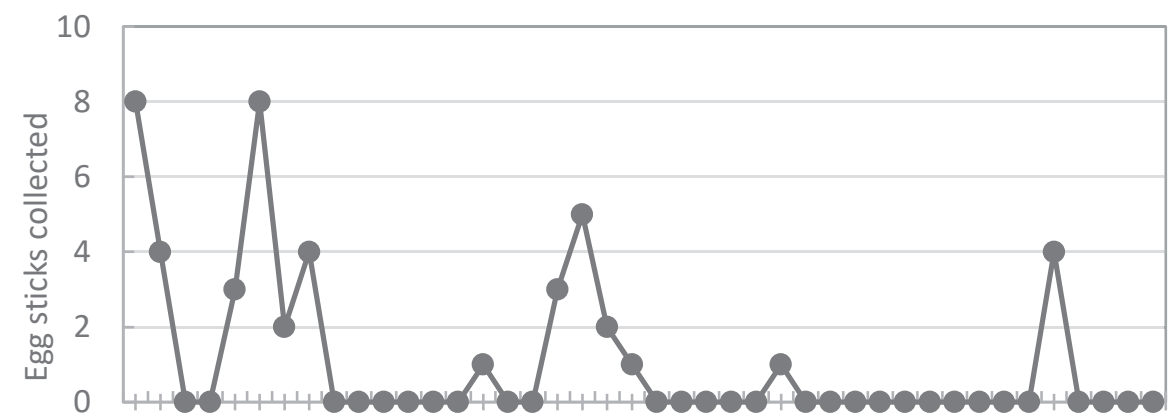

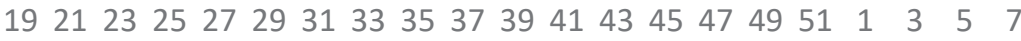

Weeks in a year

Figure 5. Total C. cactorum egg sticks collected weekly from Opuntia spp. host plants from May 2007 to February 2008 on Isla Contoy. Collections were concentrated in an area of 3 ha of the island's $317 \mathrm{ha}$.

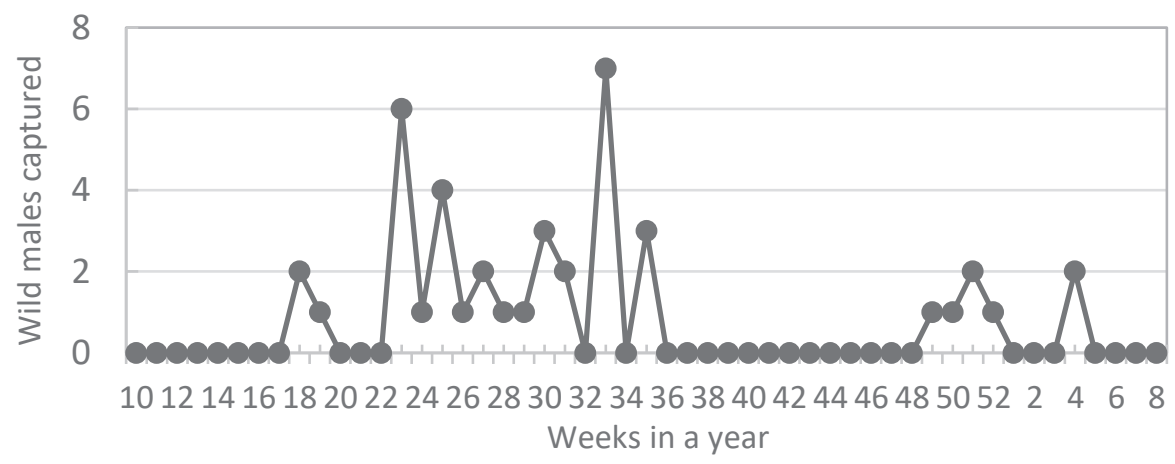

Figure 6. Total wild C. cactorum male moths caught weekly in pheromone-baited traps from March 2007 to February 2008 on Isla Contoy. Captures were concentrated in an area of 3 ha of the island's $317 \mathrm{ha}$. 
The last wild moth was captured in January 24, 2008. After conducting various field release tests, the programme carried out continued weekly releases of sterile moths, considering the biological conditions of the pest and the availability of sterile insects, from March 1, 2008 until July 2, 2008. For both islands a total of 21398 sterile moths were released, of which $75 \%$ were males.

Weekly releases of sterile moths during 4 consecutive months assured complete eradication of possible remnant $C$. cactorum populations. The sterile moths, reared and sterilized at the USDA-Agricultural Research Service (ARS) laboratory in Tifton, Georgia, were packaged in Petri dishes and shipped by commercial air cargo in insulated cardboard wrapped Styrofoam shipping boxes (KoolTempTM GTS-89 Shipping System, Cold Chain Technologies, Holliston, Massachusetts). Hight and Carpenter (2016) provide additional packaging details. Refrigerant Kool Guard II cooling bricks were included in the containers to maintain a targeted temperature around the sterile insects of $1-4^{\circ} \mathrm{C}$.

\subsection{Additional Programme Activities}

Between January 6 and February 3, 2007, 6 wild adult cactus moths were caught in traps deployed in the continental area of Cancún, on the Quintana Roo mainland. In response, activities were immediately intensified on the mainland adjacent to Isla Mujeres and Isla Contoy. Three thousand additional traps were deployed and distributed among houses, hotels and shops in the coastal area covering a total area of $22.2 \mathrm{~km}^{2}$. Wild host plants were examined in the vicinity of Nichupte Lagoon for possible detection of egg sticks or larvae. No further positive moth captures were reported after February 3, 2007, and no egg sticks were found on mainland Quintana Roo.

In the state of Quintana Roo, a trapping network was maintained with a total of 262 traps and 729 Permanent Observation Points (POPs) with Opuntia host plants present. In the neighbouring state of Yucatán (from El Cuyo to Celestum), 130 traps were deployed and 122 POPs were monitored; and in Campeche state (Rio Verde, Real de Salinas and Jaina) 79 traps were deployed and 50 POPs monitored. Traps and POPs were checked weekly and fortnightly, respectively.

Training and raising awareness activities where implemented in support of the programme. They consisted of 3 training courses, 500 radio spots, 700 posters and 4000 flyers distributed on Isla Contoy, 25000 flyers and banners in English and Spanish, 107 videos in English and Spanish distributed in the area of the Yucatán Peninsula, 6 news broadcasts on local television stations and one on national television.

Since the beginning of the eradication programme (August 2006), 6 experts from the Mexico-USA Bi-National Cooperative Programme and from the FAO/IAEA Joint Division made multiple visits to the programme and provided technical advice. 


\section{PROGRAMME OUTCOME}

In 2009, after a period equivalent to three estimated biological life cycles of the pest without any further detection, the two cactus moth outbreaks were considered eradicated from the state of Quintana Roo, maintaining Mexico free of this pest.

The following Official Agreements were published in the Official Gazette of the Mexican Federation:

- On 26 March 2009. "Agreement by which the outbreak of cactus moth (Cactoblastis cactorum Berg) was declared eradicated from Isla Mujeres, Municipality of Isla Mujeres, State of Quintana Roo” (SAGARPA 2009a).

- On 12 October 2009. "Agreement by which the outbreak of cactus moth (Cactoblastis cactorum Berg) declared eradicated from Isla Contoy, Municipality of Isla Mujeres, State of Quintana Roo" (SAGARPA 2009b).

Based on the above and in accordance with the International Standard for Phytosanitary Measures No.8 "Determination of pest status in an area" (FAO 2017), the cactus moth was considered eradicated after more than three generations without detections, and continued surveillance since then has confirmed its continuous absence from Mexico.

The National Preventive Campaign against Cactus Moth began in 2002 and continued until 2009, with eradication actions carried out under the coordination of National Plant Protection Directorate.

In 2010, the Phytosanitary Epidemiological Surveillance Programme was created and all surveillance actions against the cactus moth became part of this Programme, under the coordination of the National Phytosanitary Reference Centre. Activities under this Programme have continued and were expanded throughout the country since its creation, for timely detection of any cactus moth incursions. This preventive activity is conducted through exploratory actions, sentinel plots and trapping routes in the areas where Opuntia is commercially grown for vegetable, forage and prickly pear production.

From 2010-2017, the federal investment in surveillance activities amounts to more than USD 4.15 million (SAGARPA-SENASICA 2017) (Fig. 7).

To date there are 84105 field observations/records on the genus Opuntia entered into the National Plant Protection Directorate database (SIRVEF 2018). These observations are distributed as follows: 2841 observations at sentinel plots, 65103 observations for trapping routes (trapping with pheromone), and 11497 observations on surveillance routes (sentinel plants where the technicians look for larval damage and egg sticks of the cactus moth). The observations/records are established in 842 sentinel plots, 131 surveillance routes, and a national trapping network of 1660 traps, installed in potential strategic risk areas for the establishment of the pest (SAGARPASENASICA 2016). 


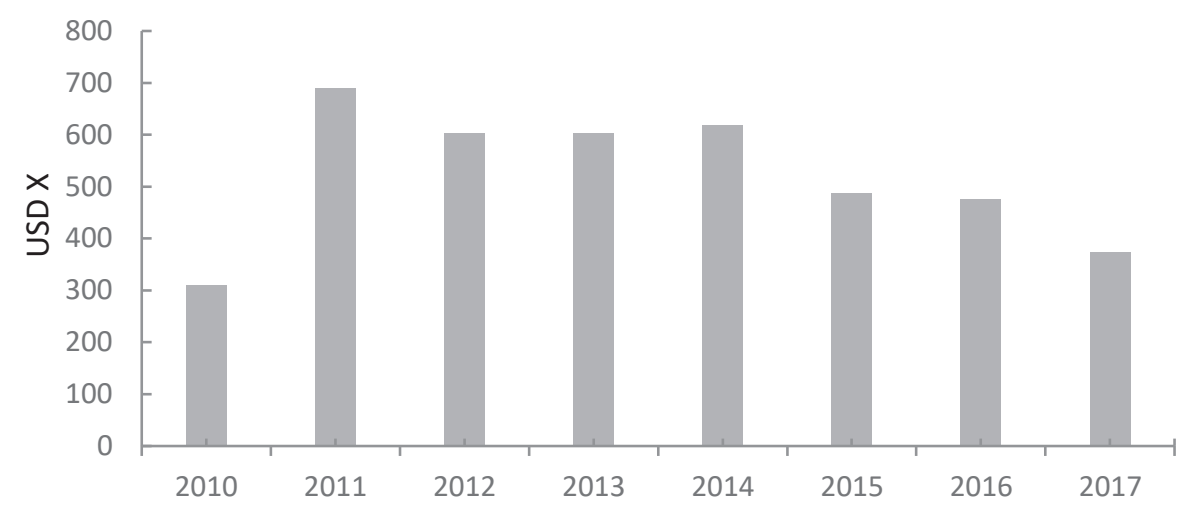

Figure 7. Yearly assigned budget for Cactoblastis cactorum preventive surveillance programme in Mexico from 2010 up to 2017.

As a result of these actions under the Phytosanitary Epidemiological Surveillance Programme, to date, no more specimens of the cactus moth have been detected anywhere in the country.

\section{FUTURE PERSPECTIVE AND ONGOING SURVEILLANCE}

It is almost inevitable that this insect will continue advancing along the USA Gulf Coast, where active containment activities are no longer ongoing. This could result in the pest eventually spreading into Texas and reaching areas adjacent to northeast Mexico, thus posing a constant threat of introduction and invasion of Mexican territory.

Pathway risk analysis has shown that the most likely routes of invasion to Mexico are from Florida including the Keys, along the Gulf Coast states to Texas, and from there to northern Mexico (Simonson et al. 2005). Likewise, Cuba is the closest island to the Caribbean coast of Mexico, and arrival of the cactus moth through this route is very likely due to its proximity with the Yucatán Peninsula, a region with large and wide-spread populations of Opuntia cacti (Sánchez et al. 2007).

Due to this permanent pest risk, it is essential to continue the preventive activities through the Phytosanitary Epidemiological Surveillance Programme. Emphasis should be placed on states that are more exposed to cactus moth entries and where Opuntia cacti are a valuable commodity. 


\section{CONCLUSIONS}

The cactus moth programme in Mexico is an example of the successful eradication of outbreaks of an invasive pest species integrating the SIT (Hendrichs et al. 2021). The AW-IPM approach was able to combine technical, social, economic, human and political resources to achieve the objective.

Nevertheless, the threat prevails and the Mexican government, under the ongoing preventive Phytosanitary Epidemiological Surveillance Programme, is prepared for the early detection and timely response to a new cactus moth incursion.

\section{ACKNOWLEDGMENTS}

We would like to express our thanks to Jose Manuel Montiel Castelan for providing data for this paper, and Roberto Jose Gomez Pauza, Selene Bello Rivera, and two anonymous reviewers for their valuable comments to an earlier draft. Appreciation is also extended to the committed men and women who worked tirelessly on the Eradication Programme that removed the invasive C. cactorum from Mexico.

\section{REFERENCES}

Barbera, G. 1995. History, economic and agro-ecological importance, pp. 1-11. In G. Barbera, P. Inglese, and E. Pimienta-Barrios (eds.), Agro-ecology, cultivation and uses of cactus pear. FAO Plant Production and Protection Paper 132. Rome, Italy.

Bloem, S., S. D. Hight, J. E. Carpenter, and K. A. Bloem. 2005a. Development of the most effective trap to monitor the presence of the cactus moth (Lepidoptera: Pyralidae). Florida Entomologist 88: 300306.

Bloem, S., R. F. Mizell, K. A. Bloem, S. D. Hight, and J. E. Carpenter. 2005b. Laboratory evaluation of insecticides for control of the invasive Cactoblastis cactorum (Lepidoptera: Pyralidae). Florida Entomologist 88: 395-400.

Bloem, K. A., S. Bloem, J. E. Carpenter, S. D. Hight, J. Floyd, and H. Zimmermann. 2007. Don't let cacto blast us: Development of a bi-national plan to stop the spread of the cactus moth Cactoblastis cactorum in North America, pp. 337-344 In M. J. B. Vreysen, A. S. Robinson, and J. Hendrichs (eds.), Area-wide control of insect pests. From research to field implementation. Springer, Dordrecht, The Netherlands.

Bravo-Hollis, H. H. 1978. Las cactáceas de México. Vol. 1. Universidad Nacional Autónoma de México, Mexico City, Mexico. 743 pp.

Carpenter, J. E., and S. D. Hight. 2012. Rearing the oligophagous Cactoblastis cactorum (Lepidoptera: Pyralidae) on meridic diets without host plant material. Florida Entomologist 95: 1132-1141.

Carpenter, J. E., K. A. Bloem, and S. Bloem. 2001. Applications of $F_{1}$ sterility for research and management of Cactoblastis cactorum (Lepidoptera: Pyralidae). Florida Entomologist 84: 531-539.

Carpenter, J. E., S. D. Hight, and A. Bello. 2008. Eradication and containment of Cactoblastis cactorum in Mexico and the United States. Abstract 1286. 23rd International Congress of Entomology Durban, South Africa, 6-12 July 2008.

Cibrián-Tovar, J. 2009. Complementing the identification of the sexual pheromone of the cactus moth, Cactoblastis cactorum Berg. Second report (February-May 2010), IAEA-USDA, Tifton, Georgia, USA. $21 \mathrm{pp}$.

Cibrián-Tovar, J., J. E. Carpenter, S. D. Hight, T. Potter, G. Logarzo, and J. C. Velázquez-González. 2017. A reinvestigation of Cactoblastis cactorum (Lepidoptera: Pyralidae) sex pheromone for improved attractiveness and greater specificity, pp. 119-131. In V. Shields (ed.), Biological control of pest and vector insects. IntechOpen, Open Access Books.

DeBach, P. 1964. Biological control of insect pests and weeds. Chapman and Hall, London, UK. 844 pp. 
DeBach, P., C. B. Huffaker, and A. W. MacPhee. 1976. Evaluation of the impact of natural enemies, pp. 255-285. In C. B. Huffaker and P. S. Messenger (eds.), Theory and practice of biological control. Academic Press, New York, USA. 788 pp.

Dodd, A.P. 1940. The Biological campaign against prickly pear. Commonwealth Prickly Pear Board, Brisbane, Australia. 177 pp.

Dickel, T. S. 1991. Cactoblastis cactorum in Florida (Lepidoptera: Pyralidae: Phycitinae). Tropical Lepidoptera 2: 117-118.

Dyck, V. A., J. Hendrichs, and A. S. Robinson (eds.). 2021. Sterile Insect Technique - Principles and practice in Area-Wide Integrated Pest Management, Second Edition. CRC Press, Boca Raton, Florida, USA. 1200 pp.

Esparza, G., R. D. Valdez, and S. J. Méndez. 2004. El nopal: tópicos de actualidad. Universidad Autónoma de Chapingo, Mexico. 303 pp.

(FAO) Food and Agriculture Organization of the United Nations. 2017. Determination of pest status in an area. International Standard for Phytosanitary Measures (ISPM) No. 8. International Plant Protection Convention (IPPC), Rome, Italy.

Flores-Valdez, C. A., and C. Gallegos. 1993. Situación y perspectivas de la producción de tuna en la región centro norte de México. Universidad Autónoma de Chapingo-CIESTAAM. Chapingo, México.

Flores-Valdez, C. A., T. M. Esquivel De Luna, and P. P. Ramírez Moreno. 1995. Mercado mundial de la tuna. Universidad Autónoma de Chapingo-CIESTAAM. Chapingo, Mexico.

Felker, P. 1995. Forage and fodder production and utilization. Agro-ecology, cultivation and uses of cactus pear, pp. 144-154. In G. Barbera, P. Inglese and E. Pimienta-Barrios (eds.), FAO Plant Production and Protection Paper 132, Rome, Italy.

Habeck, D. H., and F. D. Bennett. 1990. Cactoblastis cactorum Berg (Lepidoptera: Pyralidae) a phycitine new to Florida. Entomology Circular 333, Division of Plant Industry, Florida Department of Agriculture and Consumer Services, Tallahassee, Florida, USA. 4 pp.

Hanselka, C. W., and J. C. Paschal. 1989. Developing prickly pear as a forage, fruit, and vegetable resource. Proceedings of Conference 14 July 1989. Kingsville, Texas. Texas Agric. Ext. Serv. College Station. Texas, USA.

Heath, R. R., P. E. A. Teal., N. D. Epsky, B. D. Dueben, S. D. Hight, S. Bloem, J. E. Carpenter, T. J. Weissling, P. E. Kendra, J. Cibrián-Tovar, and K. A. Bloem. 2006. Pheromone-based attractant for males of Cactoblastis cactorum (Lepidoptera: Pyralidae). Environmental Entomology 35: 1469-1476.

Hendrichs, J., W. R. Enkerlin, and R. Pereira. 2021. Invasive insect pests: Challenges and the role of the Sterile Insect Technique in their prevention, containment, and eradication, pp. 885-922. In V. A. Dyck, J. Hendrichs, and A. S. Robinson (eds.), Sterile Insect Technique - Principles and practice in Area-Wide Integrated Pest Management, Second Edition. CRC Press, Boca Raton, Florida, USA.

Hernández, J., H. M. Sánchez, A. Bello, and G. González. 2007. Preventive programme against the cactus moth Cactoblastis cactorum in Mexico, pp. 345-350. In M. J. B. Vreysen, A. S. Robinson, and J. Hendrichs (eds.), Area-wide control of insect pests. From research to field implementation. Springer, Dordrecht, The Netherlands.

Hight, S. D., and J. E. Carpenter. 2009. Flight phenology of male Cactoblastis cactorum (Lepidoptera: Pyralidae) at different latitudes in the southeastern United States. Florida Entomologist 92: 208-216.

Hight, S. D., and J. E. Carpenter. 2016. Performance improvement through quality evaluations of sterile cactus moths, Cactoblastis cactorum (Lepidoptera: Pyralidae), mass-reared at two insectaries. Florida Entomologist 99: 206-214.

Hight, S. D., J. E. Carpenter, K. A. Bloem, S. Bloem, R. W. Pemberton, and P. Stiling. 2002. Expanding geographical range of Cactoblastis cactorum (Lepidoptera: Pyralidae) in North America. Florida Entomologist 85: 527-529.

Hight, S. D., S. Bloem, K. A. Bloem, and J. E. Carpenter. 2003. Cactoblastis cactorum (Lepidoptera: Pyralidae): Observations of courtship and mating behaviors at two locations on the Gulf Coast of Florida. Florida Entomologist 86: 400-408.

Hight, S. D., J. E. Carpenter, S. Bloem, and K. A. Bloem. 2005. Developing a sterile insect release program for Cactoblastis cactorum (Berg) (Lepidoptera: Pyralidae): Effective overflooding ratios and release-recapture field studies. Environmental Entomology 34: 850-856.

Marti, O. G., and J. E. Carpenter. 2008. Rearing Cactoblastis cactorum (Lepidoptera: Pyralidae) on a factitious meridic diet at different temperatures and larval densities. Florida Entomologist 91: 679685 . 
Marsico, T. D., L. E. Wallace, G. N. Ervin, C. P. Brooks, J. E. McClure, and M. E. Welch. 2011. Geographic patterns of genetic diversity from the native range of Cactoblastis cactorum (Berg) support the documented history of invasion and multiple introductions for invasive populations. Biological Invasions 13: 857-868.

McLean, S. C., K. A. Bloem, S. Bloem, S. D. Hight, and J. E. Carpenter. 2006. Effect of temperature and length of exposure time on percent egg hatch of Cactoblastis cactorum (Lepidoptera: Pyralidae). Florida Entomologist 89(3): 340-347.

(NAPPO) North American Plant Protection Organization. 2009. Detection and eradication of a cactus moth (Cactoblastis cactorum Berg) outbreak in Isla Contoy, municipality of Isla Mujeres, Quintana Roo, Mexico. Official Pest Reports. North American Plant Protection Organization. Ottawa, Canada.

Ojeda, A. A. 2004. Ficha de Cactoblastis cactorum. Subsecretaria de Gestión para la Protección Ambiental. Dirección General de Gestión Forestal y de Suelos. Dirección de Salud Forestal y Conservación de Recursos Genéticos. Subsecretaria de Medio Ambiente y Recursos Naturales. México.

Paraiso, O., S. D. Hight, M. T. K. Kairo, S. Bloem, J. E. Carpenter, and S. Reitz. 2012. Laboratory biological parameters of Trichogramma fuentesi (Hymenoptera: Trichogrammatidae), an egg parasitoid of Cactoblastis cactorum (Lepidoptera: Pyralidae). Florida Entomologist 95: 1-7.

Pemberton, R. W. 1995. Cactoblastis cactorum (Lepidoptera: Pyralidae) in the United States. An immigrant biological control agent or an introduction of the nursery industry? American Entomologist 41: 230-232.

Pettey, F. W. 1948. The biological control of prickly pear in South Africa. Science Bulletin, Department of Agriculture of the Union of South Africa 271: 1-163.

Pimienta-Barrios, E. 1990. El nopal tunero. Universidad de Guadalajara, Guadalajara, Jalisco, México. $246 \mathrm{pp}$.

(SAGARPA) Secretaría de Agricultura, Ganadería, Desarrollo Rural, Pesca y Alimentación. 2009a. Acuerdo mediante el cual se declara erradicado el brote de palomilla del nopal (Cactoblastis cactorum Berg.) en Isla Mujeres, Municipio de Isla Mujeres, Estado de Quintana Roo. Diario Oficial de la Federación, 26 de marzo de 2009. Ciudad de México, México.

(SAGARPA) Secretaría de Agricultura, Ganadería, Desarrollo Rural, Pesca y Alimentación. $2009 \mathrm{~b}$. Acuerdo mediante el cual se declara erradicado el brote de palomilla del nopal (Cactoblastis cactorum Berg.) en Isla Contoy, Municipio de Isla Mujeres, Estado de Quintana Roo. Diario Oficial de la Federación, 12 de octubre de 2009. Ciudad de México, México.

(SAGARPA-SENASICA) Secretaría de Agricultura, Ganadería, Desarrollo Rural, Pesca y Alimentación - Servicio Nacional de Sanidad, Inocuidad y Calidad Agroalimentaria. 2016. Palomilla del nopal Cactoblastis cactorum (Berg, 1885) (Lepidoptera: Pyralidae): Aviso público del riesgo y la situación actual. Ciudad de México, México. 7 pp.

(SAGARPA-SENASICA) Secretaría de Agricultura, Ganadería, Desarrollo Rural, Pesca y Alimentación - Servicio Nacional de Sanidad, Inocuidad y Calidad Agroalimentaria. 2017. Programas de trabajo de vigilancia epidemiológica fitosanitaria para los estados de Campeche, Coahuila, Chihuahua, Distrito Federal, México, Nuevo León, Quintana Roo, San Luis Potosí, Tabasco, Tamaulipas, Veracruz, Yucatán y Zacatecas. SENASICA-SAGARPA-PVEF. Ciudad de México, México.

Sánchez, A. H., J. Cibrián, C. J., Osorio, and C. Aldama. 2007. Impacto económico y social en caso de introducción y establecimiento de la palomilla del nopal (Cactoblastis cactorum) en México. Informe financiado por el Organismo Internacional de Energía Atómica (OIEA), (TC MEX/50/29) y presentado a la Dirección General de Sanidad Vegetal. Ciudad de México, México. 43 pp.

Sarvary, M. A., K. A. Bloem, S. Bloem, J. E. Carpenter, S. D. Hight, and S. Dorn. 2008. Diel flight pattern and flight performance of Cactoblastis cactorum (Lepidoptera: Pyralidae) measured on a flight mill: Influence of age, gender, mating status, and body size. Journal of Economic Entomology 101:314-324.

Simmonds, F. J., and F. D. Bennett. 1966. Biological control of Opuntia spp. by Cactoblastis cactorum in the Leeward Islands (West Indies). Entomophaga 11: 183-189.

Simonsen, T. J., R. L. Brown, and F. A. H. Sperling. 2008. Tracing an invasion: Phylogeography of Cactoblastis cactorum (Lepidoptera: Pyralidae) in the United States based on mitochondrial DNA. Annals of the Entomological Society of America 101: 899-905. 
Simonson, E. S., J. T. Stohlgren, L. Tyler, P. W. Gregg, R. Muir, and J. G. Lynn. 2005. Preliminary assessment of the potential impacts and risks of the invasive cactus moth, Cactoblastis cactorum Berg, in the U.S. and Mexico. Final Report to the International Atomic Energy Agency, April 25, 2005. IAEA, Vienna, Austria.

(SIRVEF) Sistema Integral de Referencia para la Vigilancia Epidemiológica Fitosanitaria. 2018. SAGARPA-SENASICA, Mexico.

Soberón, J., J. Golubov, and J. Sarukhan. 2001. The importance of Opuntia in Mexico and routes of invasion and impact of Cactoblastis cactorum (Lepidoptera: Pyralidae). Florida Entomologist 84: 486492.

Stiling, P. 2000. A worm that turned. Natural History 109(5): 40-43.

van Lenteren, J. C., and H. C. J. Godfray. 2005. European science in the Enlightenment and the discovery of the insect parasitoid life cycle in The Netherlands and Great Britain. Biological Control $32: 12-24$.

Zimmermann, H. G., and S. M. Pérez-Sandi-Cuen. 2006. The consequences of introducing the cactus moth Cactoblastis cactorum to the Caribbean and beyond. Transcontinental Reproductiones Fotomecánicas S.A. de C.V. Mexico City, Mexico. 65 pp.

Zimmermann, H. G., V. C. Moran, and J. H. Hoffmann. 2000. The renowned cactus moth, Cactoblastis cactorum: Its natural history and threat to native Opuntia floras in Mexico and the United States of America. Diversity and Distributions 6: 259-269.

Zimmermann H. G., S. Bloem, and H. Klein. 2004. Biology, history, threat, surveillance and control of the cactus moth, Cactoblastis cactorum. IAEA/FAO-BSC/CM. Vienna, Austria. 40 pp. 